Florea : Jurnal Biologi dan Pembelajarannya, 7(1), 2020, 41-47

This is an open access article under the CC-BY-SA license (https://creativecommons.org/licenses/by-sa/4.o/)

ISSN 2355-6102(print), ISSN 2502-0404(online)

DOI : 10.25273/florea.v7i1.6038

\title{
STUDI POLA INTERAKSI PERILAKU JANGKRIK (Gryllus bimaculatus ) JANTAN DAN BETINA
}

\author{
Anwari Adi Nugroho*, Namira Hanin Sal Sabilla, Dwi Setyaningrum, Fikih Putri Prastin, \\ Talila Rima Dani \\ Pendidikan Biologi, Universitas Veteran Bangun Nusantara Sukoharjo \\ *Email: anwariadinugroho@ univetbantara.ac.id
}

Diterima 13 Maret 2020, Disetujui 30 April 2020, Diterbitkan 15 Mei 2020

\begin{abstract}
The purpose of this study was to observe the behavior of male and female cricket (Gryllus bimaculatus) interactions. The objects of this study were five male crickets and one female cricket that had been isolated for twenty-four hours. This research is an exploratory descriptive study observing all male and female cricket (gryllus bimaculatus) behaviors. The research method used is ad libitum which is observing all visible activities, both social behavior and daily behavior of male and female crickets. Retrieval of data using direct observation, recording sounds and then recorded in the observation sheet, observation notes, and documentation tools. The data that has been collected is then analyzed using descriptive analysis techniques that describe the behaviors that arise during observation. The results showed that the behavior that is often performed by crickets is sounding, eating, climbing, mating and attacking other crickets. Crickets perform sounding behavior to attract the attention of female crickets, show their existence and to defend their territory and food sources. crickets also often climb, to escape from the container because crickets want to live freely. Crickets perform eating behavior to maintain life and will show aggressive behavior when fighting over food and when maintaining their partners. Female crickets will mating if captivated by male crickets.
\end{abstract}

Keywords: Cricket behavior, Gryllus bimaculatus, Interaction

\section{PENDAHULUAN}

Serangga (insekta) merupakan salah satu kelompok (kelas) dari Arthropoda yang memiliki segmentasi tubuh meliputi caput, thorax dan abdomen. Pada bagian caput (kepala) terdapat sepasang antena, Bagian kepala juga terdapat mata tunggal yang tersusun dalam satu segitiga tumpul, mulut, dan dua pasang sungut. Pada thorax terdapat enam tungkai dan empat sayap. Bagian abdomen (perut) khususnya posterior terdiri dari ruas-ruas (Corey et al., 2000). Pada ujung abdomen jangkrik jantan dan betina terdapat sepasang cerci berukuran panjang dan tajam. Cerci tersebut berfungsi menerima rangsangan dan untuk mempertahankan diri apabila terdapat musuh yang berada dibelakang tubuh jangkrik.
Jumlah spesies anggota insekta lebih banyak jika dibandingkan dengan jumlah spesies hewan-hewan lain dan terdapat ribuan spesies yang belum teridentifikasi (Radiopoetro, 1990). Jangkrik sebagai salah satu anggota dari insekta merupakan hewan serangga dari ordo orthoptera. Secara morfologi jangkrik memiliki ukuran tubuh kecil sampai besar dan memiliki hubungan kekerabatan dekat dengan belalang (Borror et al., 1996). Spesies jangkrik yang telah ditemukan berjumlah sekitar 900 jenis, sedangkan di Indonesia terdapat 123 jenis jangkrik. Widiyaningrum (2009) menjelaskan bahwa jenis jangkrik yang banyak dibudidayakan adalah Gryllus bimaculatus (Jangkrik Kalung). .

Jangkrik (Gryllus bimaculatus) jantan dan betina memiliki bentuk tubuh 
yang berbeda. Venasi sayap depan jangkrik betina berbentuk garis-garis lurus, sedangkan pada jantan berbentuk tidak beraturan seperti melingkar dan ada yang lurus. Pada jangkrik jantan juga terdapat stridulasi yang berfungsi untuk menghasilkan suara atau mengerik. Suara mengerik dihasilkan dari bagian kasar sayap depan yang bergesekan dan bagian kasar pada sayap belakang. Pada sayap terdapat struktur harp yaitu struktur sayap yang berfungsi memperbesar suara yang dihasilkan oleh bagian kasar dibalik sayap depan dan bagian kasar pada sayap belakang. Suara yang dihasilkan jangkrik memiliki nada yang berfungsi untuk menarik perhatian jangkrik betina atau perilaku agonistik. Suara tersebuti dapat dihasilkan pada saat sayap jangkrik jantan terangkat.

Pada jangkrik betina memiliki alat yang berfungsi sebagai penangkap suara atau "telinga" yang terletak dibagian timpanum di tungkai depan. Suara yang dihasilkan jangkrik jantan berperan untuk menarik perhatian jangkrik betina, hanya individu-individu pasangan jenisnya yang dapat menangkap suara dan menemukan pasangannya (Erniwati, 2012).

Habitat jangkrik ditemukan pada kayu lapuk, bagian bawah batu-batuan dan pada lubang - lubang tanah serta di semak-semak belukar. Jangkrik merupakan hewan yang hidup secara bergerombol dan bersembunyi pada lipatan- lipatan daun kering atau bongkahan tanah (Paimin, 1999).

Secara perilaku, jangkrik jantan dan betina memiliki perilaku yang sama dan terdapat pula perilaku yang khas. Perilaku jangkrik yang sering muncul akibat interaksi antara jantan maupun betina yaitu perilaku agonistik yang terkait dengan pertarungan. Agonistik jangkrik berupa perilaku mengancam dan menunjukkan kekuatan pada hewan sejenisnya. Scott \& Fredericson (1951) menjelaskan perilaku agonistik banyak ditemui pada hewan-hewan yang terbatas makanan, tempat tinggal, dan pasangannya. Kadang - kadang hewan juga menunjukkan kekuatan kepada lawannya yang membuat mereka terlihat lebih kuat dan besar serta dengan perilaku itu dapat memperoleh sumber daya tanpa melalui pertarungan.

Apabila jangkrik jantan dan jangkrik jantan lainnya ditempatkan dalam satu terrarium maka akan timbul perilaku sebagai akibat interaksi dengan lainnya sehingga dapat terjadi pertarungan untuk mempertahankan daerah kekuasaannya bahkan saling memangsa. Pada penelitian ini dilakukan pengamatan untuk mengetahui perilaku interaksi jangkrik (Gryllus bimaculatus) jantan dan betina yang ditempatkan dalam terrarium.

\section{METODE PENELITIAN}

Penelitian ini dilakukan di Laboraturium Universitas Veteran Bangun Nusantara Sukoharjo dan dilakukan pada bulan Desember 2019 Januari 2020. Jenis penelitian adalah penelitian deskriptif eksploratif. dengan melakukan pengamatan langsung terhadap perilaku agonistik jangkrik (Gryllus bimaculatus) jantan dan betina. Penelitian ini dilakukan selama 3 hari dan setiap hari diamati 2 kali yaitu pada pagi hari (pukul 07.00 - 09.00) dan malam hari (pukul 20.00 - 22.00).

Metode penelitian yang digunakan adalah ad libitum sampling dengan menggunakan jenis jangkrik (Gryllus bimaculatus) jantan dan betina. Metode ad libitum sampling adalah metode dengan mengamati semua perilaku individu berdasarkan fakta yang ada dilapangan dan tanpa adanya potongan waktu. Bahan yang digunakan dalam penelitian ini adalah jangkrik jantan sebanyak 5 ekor dan jangkrik betina sebanyak 1 ekor. Alat - alat yang dibutuhkan seperi terraium sebanyak 7 buah, tali sebanyak 6 buah, alat untuk merekam suara sebanyak 1 buah, kamera sebanyak 1 buah. 
Prosedur penelitian pola perilaku jangkrik (Gryllus bimaculatus) jantan dan betina dapat dilihat pada Gambar 1.

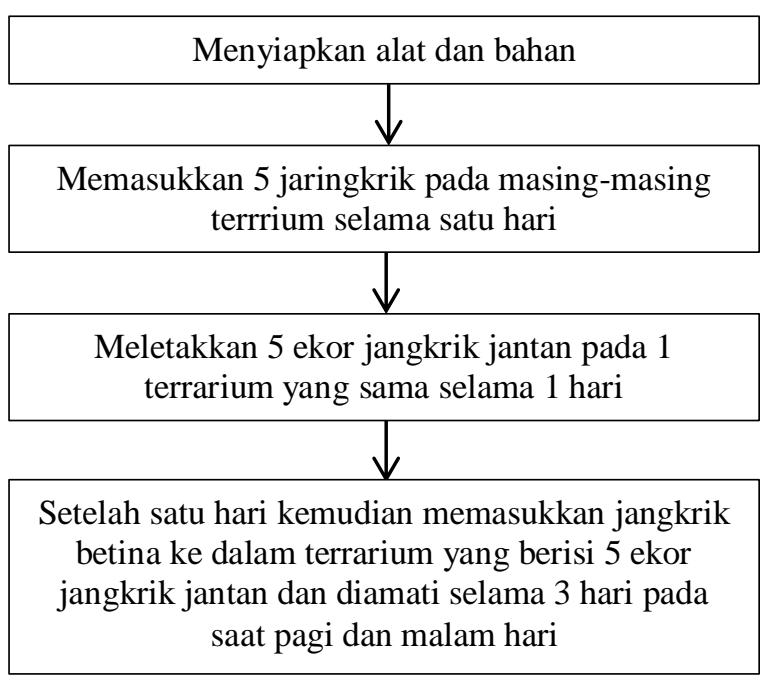

Gambar 1. Prosedur Penelitian

Penjelasan gambar 1 sebagai berikut: 1) Menyiapkan alat dan bahan dalam penelitian;

2) Meletakkan 5 ekor jangkik pada terarium yang berbeda. Desain penelitian dari pengamatan pola perilaku jangkrik jantan dan betina dapat dilihat pada Gambar 2.

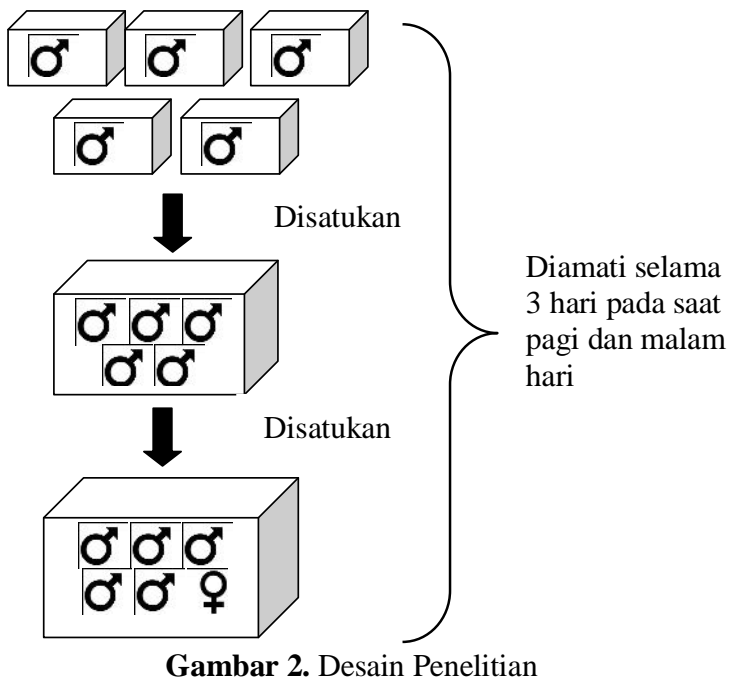

3) Mengamati perilaku jangkrik jantan dan betina selama 1 hari pada waktu pagi dan malam hari masing - masing selama 2 jam. 4) Menggabungkan jangkrik jantan dalam satu terrarium yang sama selama 1 hari dan diamati pada pagi dan malam hari. 5) Menggabungkan 5 ekor jangkrik jantan dan 1 ekor betina dan mengamati selama 3 hari pengamatan dilakukan pada pagi hari dan malam hari sama seperti penelitian sebelumnya. Pada saat malam hari pengamatan menggunakan perekam suara. 5) Mencatat perilaku jangkrik jantan dan betina pada lembar pengamatan.

Data diambil dengan cara pengamatan menggunakan lembar pengamatan, alat perekam suara dan alat dokumentasi. Data yang sudah dikumpulkan dianalisis menggunakan teknik analisis deskriptif yaitu mendeskripsikan perilaku-perilaku yang muncul selama pengamatan.

\section{HASIL DAN PEMBAHASAN}

Jangkrik (Gryllus bimaculatus) merupakan hewan serangga (insekta) dari ordo orthoptera. Secara morfologi jangkrik memiliki ukuran tubuh kecil sampai besar (Borror et al., 1996). Venasi sayap depan jangkrik betina berbentuk garis-garis lurus, sedangkan pada jantan berbentuk tidak beraturan seperti melingkar dan ada yang lurus. Pada jangkrik jantan juga terdapat stridulasi yang berfungsi untuk menghasilkan suara atau mengerik.

Klasifikasi ilmiah (Borror et al., 1996).

$\begin{array}{ll}\text { Kingdom } & \text { : Animalia } \\ \text { Filum } & \text { : Arthropoda } \\ \text { Kelas } & \text { : Insecta } \\ \text { Ordo } & \text { : Orthoptera } \\ \text { Family } & : \text { Gryllidae } \\ \text { Genus } & \text { : Gryllus } \\ \text { Spesies } & \text { : Gryllus bimaculatus }\end{array}$

Secara perilaku, jangkrik jantan dan betina memiliki perilaku yang sama dan terdapat pula perilaku yang khas. Perilaku jangkrik yang sering muncul akibat interaksi antara jantan maupun betina yaitu perilaku agonistik yang terkait dengan pertarungan. Apabila jangkrik jantan dan jangkrik jantan lainnya ditempatkan dalam satu terrarium maka akan timbul perilaku sebagai akibat adanya interaksi.

Kegiatan pertama pada penelitian yaitu lima ekor jangkrik jantan 
dimasukkan dalam satu terrarium setelah sebelumnya diisolasi selama 24 jam. Penelitian dilakukan pada pagi dan malam hari. Hasil penelitian saat pagi hari pada pukul $08.00-10.00 \mathrm{WIB}$ dapat dilihat pada tabel 1 .

Tabel 1. Pengamatan Sebelum Dimasukkan Jangkrik

Betina Pada Pukul 08.00 - 10.00 WIB.

\begin{tabular}{|c|c|c|c|c|c|c|}
\hline \multirow[b]{2}{*}{ No } & \multirow[b]{2}{*}{ Perilaku } & \multicolumn{5}{|c|}{ Jumlah Perilaku Muncul } \\
\hline & & \% & $\overline{2}$ & $\sigma_{3}^{x}$ & \% & $\sigma_{5}^{5}$ \\
\hline 1 & Berbunyi & 1 & 0 & 20 & 2 & 7 \\
\hline 2 & Memanjat & 2 & 5 & 1 & 6 & 1 \\
\hline 3 & $\begin{array}{l}\text { Menyerang } \\
\text { jangkrik lain }\end{array}$ & 7 & 0 & 22 & 0 & 4 \\
\hline 4 & $\begin{array}{l}\text { Menggaruk } \\
\text { badan }\end{array}$ & 0 & 3 & 3 & 6 & 1 \\
\hline 5 & Makan & 3 & 0 & 3 & 3 & 9 \\
\hline 6 & $\begin{array}{l}\text { Melompat } \\
\text { keluar wadah }\end{array}$ & 0 & 0 & 0 & 1 & 0 \\
\hline
\end{tabular}

Berdasarkan Tabel 1 dapat dijelaskan bahwa pada saat pagi hari perilaku jangkrik jantan yang dominan adalah menyerang jangkrik lain. Pada saat lima ekor jangkrik jantan disatukan dalam terrarium yang sama, mereka menyerang jangkrik yang lain untuk mempertahankan daerah kekuasaannya dan memperebutkan makanan (Gambar 3, Gambar 4). Sukarno (1999) menegaskan, apabila jangkrik dipelihara dalam kandang yang sama, maka akan mudah timbul perkelahian terutama pada kondisi kekurangan makanan, jumlah jangkrik terlalu banyak dan berdesakdesakkan dalam kandang pemeliharaan, serta lingkungan yang pengap dengan sirkulasi udara yang tidak lancar.

Perilaku lainnya yang sering dilakukan saat pagi hari yaitu berbunyi. Dari Tabel 1 dapat diketahui bahwa jangkrik nomor 3 adalah jangkrik jantan yang paling banyak berbunyi. Perilaku ini dilakukan oleh jangkrik jantan ketika suhu lingkungan dalam keadaan panas. Selain itu, pada pagi hari jangkrik sering melakukan aktivitas yaitu makan. Hal ini dikarenakan jangkrik membutuhkan banyak energi. Menurut Gunawan (2019) pada pagi hari makhluk hidup membutuhkan makanan sebagai sumber energi untuk beraktivitas

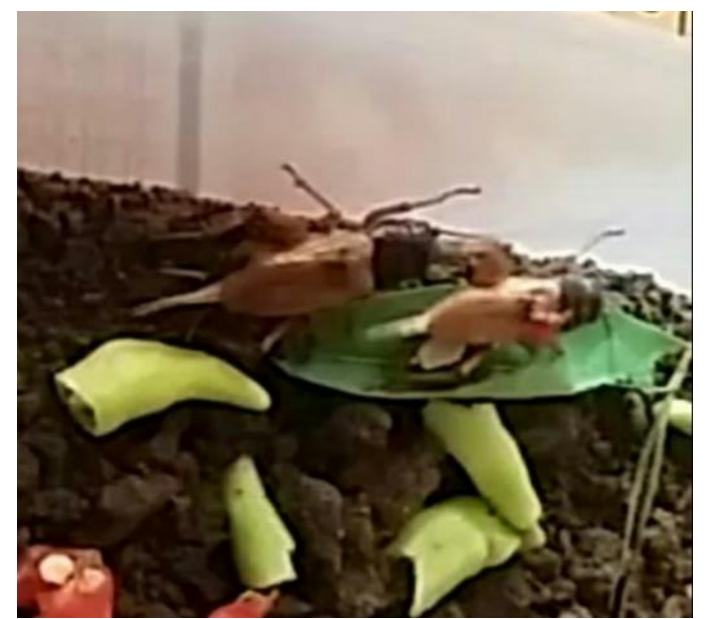

Gambar 3. Jangkrik Sedang Menyerang Jangkrik Lainnya

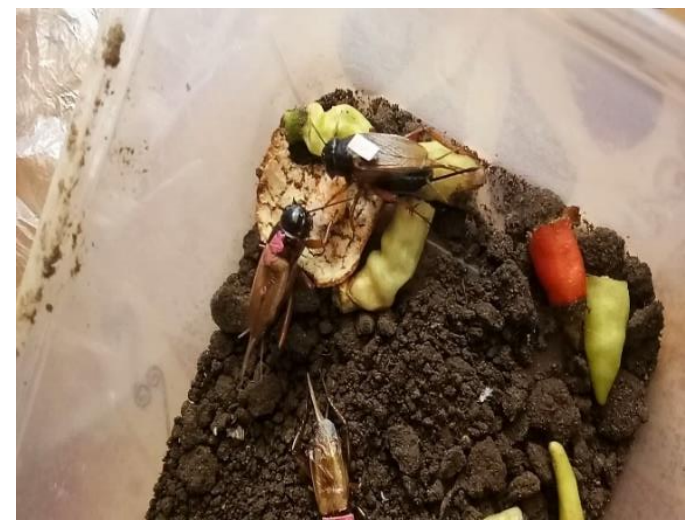

Gambar 4. Dua Ekor Jangkrik Sedang Memperebutkan Makanan

Pada saat penelitian, di dalam terrarium disediakan makanan berupa cabai dan daun-daunan. Jangkrik lebih banyak memakan cabai dari pada daun (Gambar 5). Berdasarkan wawancara langsung dengan peternak jangkrik menyatakan bahwa cabai dapat mempengaruhi bunyi yang dihasilkan oleh jangkrik. Bunyi yang dihasilkan setelah memakan cabai akan lebih nyaring. Pakan berupa daun-daun hijau juga penting untuk nutrisi jangkrik. Hasanah (2015) menjelaskan bahwa aneka pakan hijauan dapat meningkatkan daya tahan hidup jangkrik kalung (Gryllus bimaculatus).

Selain daun dan cabai jangkrik juga memakan sesama spesiesnya. Hal ini 
dikarenakan jangkrik merupakan hewan omnivora, yaitu hewan pemakan segala jenis makanan.

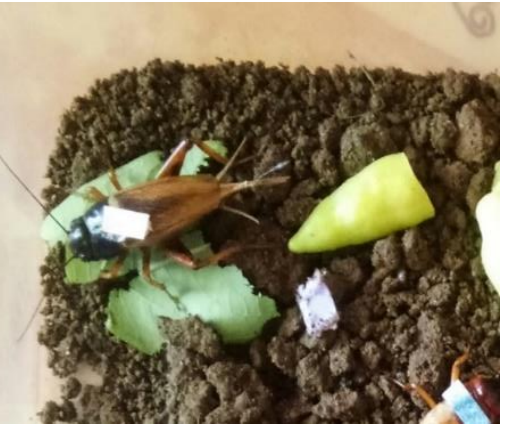

Gambar 5. Jangkrik Sedang Memakan Daun

Pengamatan berikutnya dilakukan pada malam hari selama 2 jam. Perilaku jangkrik dapat dilihat pada tabel 2.

Tabel 2. Pengamatan Sebelum Dimasukkan Jangkrik

Betina Pada Pukul 20.00 - 22.00 WIB.

\begin{tabular}{lllllll}
\hline \multirow{2}{*}{ No } & \multirow{2}{*}{ Perilaku } & \multicolumn{6}{c}{ Jumlah Perilaku Muncul } \\
\cline { 3 - 7 } & $\mathbf{\sigma}$ & $\mathbf{\sigma}$ & $\mathbf{\sigma}$ & $\mathbf{\sigma}$ & $\mathbf{\sigma}^{\prime}$ \\
\hline 1 & Berbunyi & 0 & 0 & 7 & 0 & 0 \\
\hline 2 & Memanjat & 1 & 1 & 0 & 0 & 0 \\
\hline 3 & $\begin{array}{l}\text { Menyerang } \\
\text { jangkrik lain }\end{array}$ & 2 & 1 & 5 & 0 & 3 \\
\hline 4 & $\begin{array}{l}\text { Menggaruk } \\
\text { badan }\end{array}$ & 0 & 0 & 1 & 3 & 0 \\
\hline 5 & Makan & 6 & 3 & 3 & 4 & 3 \\
\hline 6 & $\begin{array}{l}\text { Melompat } \\
\text { keluar wadah }\end{array}$ & 0 & 0 & 0 & 1 & 0 \\
\hline 7. & $\begin{array}{l}\text { Menindih } \\
\text { jangkrik lain }\end{array}$ & 0 & 0 & 0 & 0 & 1 \\
\hline 8. & $\begin{array}{l}\text { Menegepakan } \\
\text { sayap }\end{array}$ & 0 & 2 & 0 & 1 & 0 \\
\hline
\end{tabular}

Pada saat malam hari perilaku yang dominan dilakukan oleh jangkrik adalah makan. Hal ini sesuai dengan penjelasan Widani \& Chandrawati (2019) yang menyatakan bahwa jangkrik adalah hewan nokturnal, jangkrik lebih banyak beraktivitas saat malam hari, sehingga jangkrik mempunyai kebiasaan mencari makanan saat malam hari.

Perilaku lain yang dilakukan jangkrik saat malam hari adalah mengepakkan sayapnya (Gambar 6). Biasanya jangkrik jantan mengangkat sayapnya saat akan mengeluarkan bunyi. Hal ini dilakukan untuk berkomunikasi dengan jangkrik yang lain. Widani \& Chandrawati (2019) menyatakan bahwa jangkrik mengeluarkan suara nyaring yang berasal dari getaran bulu sayapnya yang saling bersentuhan. Perilaku yang jarang dilakukan oleh jangkrik jantan saat malam hari yaitu melompat keluar wadah, dan menindih jangkrik lain.

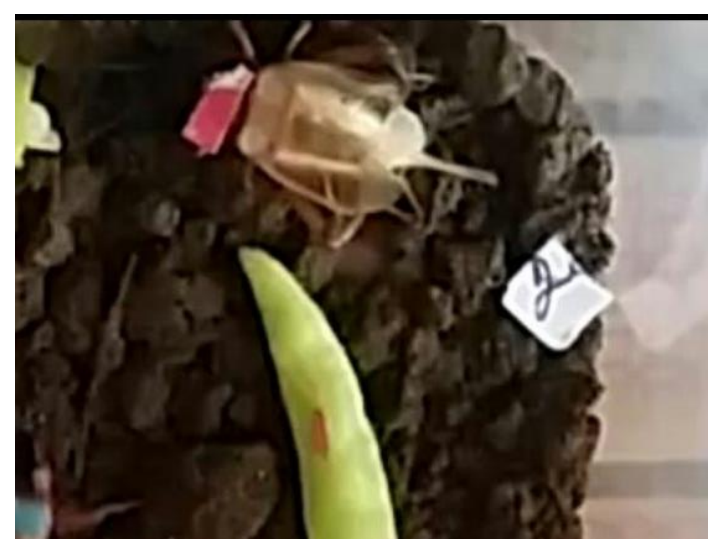

Gambar 6. Jangkrik Sedang Mengangkat Sayapnya

Setelah 5 ekor jangkrik jantan ditempatkan pada terrarium yang sama selama 1 hari kemudian dimasukkan 1 ekor jangkrik betina yang sebelumnya sudah diisolasi selama 24 jam dan diamati selama 3 hari. Hasil dari pengamatan dapat dilihat pada Tabel 3.

Tabel 3. Pengamatan Sesudah Dimasukkan Jangkrik Betina Pukul 08.00 - 10.00.

\begin{tabular}{|c|c|c|c|c|c|c|}
\hline \multirow[b]{2}{*}{ Perilaku } & \multicolumn{6}{|c|}{ Jumlah Perilaku Muncul } \\
\hline & $\sigma_{1}$ & & $\boldsymbol{\sigma}_{3}^{\bar{x}}$ & & $\mathbf{\sigma}_{5}$ & 6 \\
\hline Berbunyi & 60 & 0 & 41 & 2 & 23 & 0 \\
\hline Makan & 12 & 0 & 11 & 0 & 11 & 12 \\
\hline Memanjat & 1 & 0 & 14 & 0 & 10 & 16 \\
\hline $\begin{array}{l}\text { Menyerang } \\
\text { Jangkrik lain }\end{array}$ & 14 & 0 & 9 & 1 & 3 & 7 \\
\hline Mating & 7 & 0 & 6 & 1 & 4 & 18 \\
\hline $\begin{array}{l}\text { Menindih } \\
\text { jangkrik lain }\end{array}$ & 3 & 0 & 1 & 0 & 0 & 0 \\
\hline $\begin{array}{l}\text { Menggaruk } \\
\text { badan }\end{array}$ & 0 & 0 & 0 & 0 & 1 & 3 \\
\hline $\begin{array}{l}\text { Melompat } \\
\text { keluar wadah }\end{array}$ & 0 & 0 & 1 & 0 & 0 & 1 \\
\hline $\begin{array}{l}\text { Menggoyang } \\
\text { kan ekor }\end{array}$ & 0 & 0 & 0 & 0 & 1 & 0 \\
\hline $\begin{array}{l}\text { Membengkok } \\
\text { kan badan }\end{array}$ & 0 & 0 & 0 & 0 & 1 & 0 \\
\hline
\end{tabular}


Perilaku jangkrik jantan yang dominan setelah dimasukkan jangkrik betina adalah berbunyi. Perilaku ini dilakukan oleh jangkrik jantan untuk menunjukkan eksistensinya dan menarik perhatian jangkrik betina. Gunawan (2019) menyatakan bahwa Jangkrik jantan mengeluarkan suara yang digunakan untuk menarik perhatian jangkrik betina dan menolak jangkrik jantan lainnya. Suara jangkrik itu semakin keras dengan naiknya suhu sekitar. Pada saat jangkrik betina terpikat oleh jangkrik jantan, maka jangkrik jantan dan betina akan melakukan mating. Mating dilakukan dengan cara jangkrik betina berada diatas tubuh jangkrik jantan. Setelah itu jangkrik jantan akan mengeluarkan sperma dan diletakkan pada alat reproduksi jangkrik betina. Jangkrik betina sering melakukan mating karena di dalam terrarium terdapat banyak jangkrik jantan. Sehingga jangkrik betina melakukan mating bukan hanya dengan satu ekor jangkrik jantan, tetapi dengan semua jangkrik jantan yang berada dalam terrarium

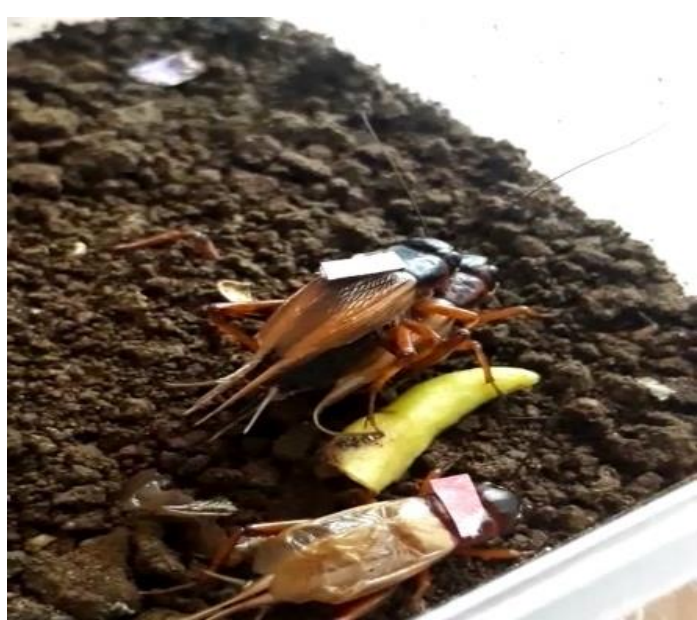

Gambar 3. Jangkrik Jantan dan Betina yang Sedang Melakukan Mating

Pengamatan selanjutnya dilakukan pada malam hari selama 3 hari berturut-turut. Perilaku jangkrik dapat dilihat pada Tabel 4.
Tabel 4. Pengamatan Sesudah Dimasukkan Jangkrik Betina Pukul 20.00 - 22.00.

\begin{tabular}{|c|c|c|c|c|c|c|}
\hline \multirow[b]{2}{*}{ Perilaku } & \multicolumn{6}{|c|}{ Jumlah Kegiatan } \\
\hline & $\sigma_{1}$ & $\underset{2}{\sigma}$ & $\sigma_{3}$ & $\boldsymbol{\sigma}_{4}$ & $\underset{5}{\sigma}$ & \\
\hline Berbunyi & 45 & 0 & 46 & 1 & 17 & 0 \\
\hline Makan & 3 & 0 & 3 & 0 & 7 & 10 \\
\hline Memanjat & 3 & 0 & 11 & 18 & 7 & 29 \\
\hline $\begin{array}{l}\text { Menyerang } \\
\text { Jangkrik lain }\end{array}$ & 7 & 0 & 15 & 0 & 4 & 1 \\
\hline Mating & 7 & 0 & 1 & 0 & 5 & 13 \\
\hline $\begin{array}{l}\text { Menindih } \\
\text { jangkrik lain }\end{array}$ & 0 & 0 & 1 & 0 & 0 & 1 \\
\hline $\begin{array}{l}\text { Menggaruk } \\
\text { badan }\end{array}$ & 8 & 0 & 0 & 0 & 1 & 2 \\
\hline $\begin{array}{l}\text { Melompat } \\
\text { keluar wadah }\end{array}$ & 0 & 0 & 0 & 0 & 0 & 1 \\
\hline $\begin{array}{l}\text { Menggoyang } \\
\text { kan ekor }\end{array}$ & 0 & 0 & 1 & 0 & 0 & 3 \\
\hline $\begin{array}{l}\text { Membengkok } \\
\text { kan badan }\end{array}$ & 0 & 0 & 0 & 0 & 0 & 1 \\
\hline
\end{tabular}

Pada pengamatan di malam hari jangrik banyak berbunyi dan melakukan mating. Hal ini sesuai dengan penjelasan Hasanah (2015) yang menyatakan bahwa di alam aslinya jangkrik hidup aktif di malam hari, kegiatan makan, mengerik dan kawin dilakukan pada malam hari. Selain itu jangkrik juga melakukan perilaku memanjat. Perilaku ini dikarenakan jangkrik merupakan hewan liar sehingga memiliki karakterisitik ingin hidup bebas di alam. Pada pengamatan, perilaku yang jarang dilakukan oleh jangkrik yaitu melompat keluar wadah, menggoyangkan ekor dan membengkokkan badan.

Selama lima hari dilakukan pengamatan, tidaksemua jangkrik bertahan hidup sampai hari terakhir, hanya dua ekor jangkrik yang bertahan hidup yaitu satu ekor jangrik betina dan satu ekor jangkrik jantan (Gambar 6). Empat ekor jangkrik lainnnya mati satu per satu setelah diserang dan dimakan oleh jangkrik yang lain.

Paimin (1999) menjelaskan bahwa jangkrik memiliki sifat kanibal yaitu saling memangsa sejenis terutama sesama jangkrik yang fisiknya lebih kecil atau lebih lemah. Sifat kanibal sering muncul apabila ruang geraknya terlalu 
sempit atau padat, kondisi lingkungan yang terlalu panas atau kekurangan makanan. Briffa (2007) menjelaskan pertarungan antar jangkrik, ada yang sampai mati dikarenakan jangkrik yang mati memiliki daya tarung (energi) yang rendah, ukuran tubuh yang lebih kcil, dan senjata yang lebih kecil.

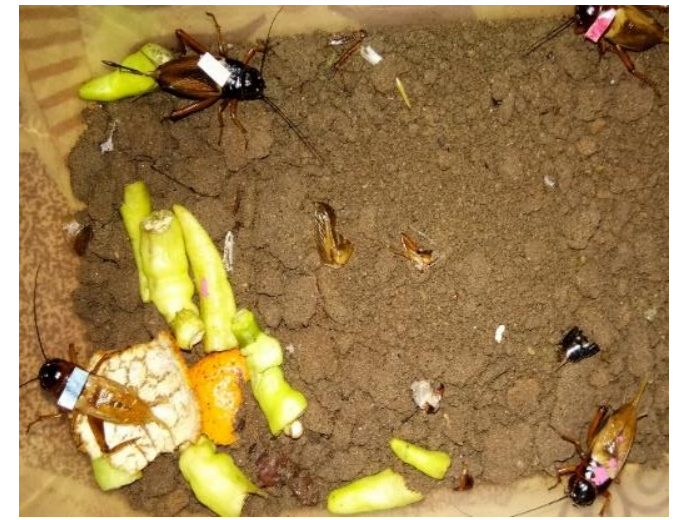

Gambar 6. Jangkrik Mati yang Bagian Tubuhnya Hancur Karena Diserang oleh Jangkrik Lain

Perilaku jangkrik jantan dan betina saat pagi dan malam hari relatif sama, yaitu berbunyi, memanjat, makan, menggaruk badan, melompat, mengangkat sayap, mating, menindih jangkrik lain, menggoyangkan ekor dan membengkokkan badan.

\section{SIMPULAN}

Perilaku yang sering dilakukan oleh jangkrik adalah berbunyi, makan, memanjat, mating dan menyerang jangkrik lain. Jangkrik melakukan perilaku berbunyi untuk menarik perhatian jangkrik betina, menunjukkan eksitensi dirinya dan untuk mempertahankan daerah kekuasaannya serta sumber makanannya. Selain berbunyi jangkrik juga sering memanjat, untuk melepaskan diri dari wadah karena jangkrik ingin hidup bebas. Jangkrik melakukan perilaku makan untuk mempertahankan hidup. Jangkrik akan menunjukkan perilaku agresif pada saat memperebutkan makanan dan pada saat mempertahankan pasangannya. Jangkrik betina akan melakukan mating apabila terpikat oleh jangkrik jantan.

\section{DAFTAR PUSTAKA}

Briffa, M. (2008). Decisions during fights in the house cricket, Acheta domesticus: mutual or self assessment of energy, weapons and size? Animal Behaviour, 75(3), 1053-1062.

Borror, D. J., Triplehorn, C. A., \& Johnson, N. F. (1996). Pengenalan Pelajaran Serangga Edisi ke-6. $S$. Partosoedjono, penerjemah. Yogyakarta: Gajahmada University Press.

Corey, S., B. Holy., N. Patrick, \& B. Patrick. (2000). Crickets. 1st Ed. Arizona University, Arizona.

Erniwati. (2019). Biologi Jangkrik (Orthoptera: Gryllidae) Budidaya Dan Peranannya. Fauna Indonesia. 11(2).

Gunawan, H. (2019). Mendulang Untung dari Budidaya Jangkrik. Laksana.

Hasanah, U. (2015). Pengaruh pemberian aneka pakan hijauan yang berbeda terhadap daya tahan hidup jangkrik kalung (gryllus bimaculatus)

(Doctoral dissertation, IAIN Palangka Raya).

Paimin, F. B., (1999). Mengatasi Permasalahan Beternak Jangkrik. Jakarta: PT. Penebar Swadaya.

Radiopoetro. (1996). Zoologi. Jakarta: Erlangga.

Scott, J. P. \& Frederickson, E. (1951). Physiol. Zool. 24, 273.

Sukarno. (1999). Budidaya Jangkrik. Yogyakarta: Kanisius.

Widani, N. N., \& Chandrawati, A. K. S. (2019, March). Be Jangkrik Dan Be Bluang Sebagai Kuliner Musiman Di Bali. Journey 1(1) 